\title{
Self-incompatibility in pears (Pyrus communis L., Pyrus serotina Rehd. and Pyrus ussuriensis) Review
}

\author{
Halász, $\mathrm{J}^{1}$ \& Hegedüs, $\mathrm{A} .^{2}$ \\ ${ }^{I}$ Corvinus University of Budapest, Faculty of Horticultural Science, Department of Genetics and Plant Breeding, \\ 1118 Budapest, Ménesi út 44., Hungary \\ ${ }^{2}$ Corvinus University of Budapest, Faculty of Food Science, Department of Applied Chemistry, \\ 1118 Budapest, Villányi út 29., HungaryE-mail: julia.halasz@stud.uni-corvinus.hu
}

\begin{abstract}
Summary: Self-incompatibility system and allele pool of three different pear species, European pear (Pyrus communis), Japanese pear ( $P$. serotina) and Chinese pear ( $P$. ussuriensis) are displayed. Several inconsistencies and the absence of the harmonization of three different allele series are revealed in the European pears. By collecting data from several reports eight incompatibility groups of Japanese pear cultivars could be established. A self-compatible genotype is analysed in details and shown to be a stylar-part mutant. As Japanese pear was the first fruit tree species from which $S$-ribonucleases were identified, the history of $S$-genotyping from the beginning to the latest achievements and technical developments can be also monitored from the experiments enumerated. In Chinese pears, seven $S$-alleles and one incompatibility group could be identified.
\end{abstract}

Key words: pear, Pyrus spp., self-incompatibility, S-genotype, incompatibility group

In 2005 pear production in the world totalled at a level of 19,513,699 Mt (Faostat, 2005). Most of the commercial pear and quince cultivars are self-incompatible (Szabó et al., 1999; Nyéki \& Soltész, 2003), which is a gametophytic trait controlled by the so-called $S$-locus. This locus is a multigene complex: an $S$-RNase gene is expressed in pistil and an $S$ haplotype-specific F-box gene in the pollen tubes. Self/nonself recognition process and the consequent acceptance or rejection takes place between the protein products of these genes. Similarly to apple, some pear cultivars are also predisposed to parthenocarpous fruit set (Nyéki \& Soltész, 2003), thereby the evaluation of seed content of fruits resulting from controlled crosses must be taken into consideration when self-(in)compatibility properties are analyzed through the classical fruit set studies (see below).

\section{Fertility properties of European pear cultivars (Pyrus communis L.)}

Most pear cultivars have been traditionally considered as completely or almost completely self-incompatible (Crane \& Lewis, 1942), while some of them can be partially selfcompatible, depending on the environment (Griggs \& Iwakiri, 1954; Nyéki et al., 2000). The firs report available on the $S$-genotypes of European pear cultivars was published by Tomimoto et al. (1996). In eight cultivars nine $S$-alleles were identified by 2D-PAGE (Table 1 ).
In most breeding programs developed in the last decades 'Williams' and 'Coscia' cultivars were often used as parental lines (Morettini, 1957; Bellini et al., 2000). This fact resulted in an increase in the frequency of the $S$-alleles from these two cultivars within the new hybrids and it increased the cases of cross-incompatibility in pear. Sanzol \& Herrero (2002) developed a reliable in vivo method to test pollen-pistil incompatibility in pear: pollen tube performance was studied along the pistil following self- and cross pollination. Their results show that ovule observation at the microscope for the presence of pollen tube in the nucellus is a proper method to test incompatibility in this crop, in contrast to pollen tube growth in the style, which may be an unclear test. The $S$ allele constitution of six commercial pear cultivars was determined on the basis of the compatibility relationships and their parentage relationship. The alleles allocated to these cultivars were named as $S_{1}, S_{2}, S_{3}$ and $S_{4}$. However, it must be mentioned that these results are not reconciled with the previous allele designation used by Tomimoto et al. (1996), therefore these allele labels must only be considered as showing the interrelationships among the given six cultivars used in the study. The authors found two crosses inter-incompatible in both ways: 'Agua de Aranjuez' $\times$ 'Butirra Precoz Morettini' and 'Santa Maria Morettini $\times$ 'S(AA $\times \mathrm{W}) 7$ ' (Table 1).

Zuccherelli et al. (2002) determined the S-locus composition of ten European pear cultivars via $S$-PCR molecular assay using apple primers, and a subsequent digestion with restriction endonucleases. The identified 
Table 1. S-allele constitution of several European pear cultivars

\begin{tabular}{|c|c|c|}
\hline Cultivar & S-genotype & Reference \\
\hline $\begin{array}{l}\text { Grand Champion } \\
\text { Alexandle Doullard } \\
\text { Doyenne du Comice } \\
\text { Bartlett } \\
\text { Flemish Beauty } \\
\text { Le France } \\
\text { Le Lectier } \\
\text { General Leclerc }\end{array}$ & $\begin{array}{l}S_{1} S_{2} \\
S_{1} S_{2} \\
S_{3} S_{4} \\
S_{5} S_{6} \\
S_{5} S_{6} \\
S_{5} \\
S_{7} S_{8} \\
S_{2} S_{9}\end{array}$ & $\begin{array}{l}\text { Tomimoto et al., } 1996 \\
\text { Tomimoto et al., } 1996 \\
\text { Tomimoto et al., } 1996 \\
\text { Tomimoto et al., } 1996 \\
\text { Tomimoto et al., } 1996 \\
\text { Tomimoto et al., } 1996 \\
\text { Tomimoto et al., } 1996 \\
\text { Tomimoto et al., } 1996\end{array}$ \\
\hline $\begin{array}{l}\text { Agua de Aranjuez } \\
\text { Butirra Precoce Morettini } \\
\text { Santa Maria Morettini } \\
\text { S }(\text { AA } \times W) 7 \\
\text { Williams } \\
\text { Coscia } \\
\text { Tosca }\end{array}$ & $\begin{array}{c}S_{1} S_{3} \\
S_{1} S_{3} \\
S_{2} S_{3} \\
S_{2} S_{3} \\
S_{1} S_{2} \\
S_{3} S_{4}\left(S_{\mathrm{b}} S_{\mathrm{k}}\right) \\
S_{1} S_{4}\end{array}$ & $\begin{array}{l}\text { Sanzol \& Herrero, } 2002^{*} \\
\text { Sanzol \& Herrero, } 2002^{\circ} \\
\text { Sanzol \& Herrero, } 2002^{\circ} \\
\text { Sanzol \& Herrero, } 2002^{*} \\
\text { Sanzol \& Herrero, } 2002^{\circ} \\
\text { Sanzol \& Herrero, } 2002^{\circ} \\
\text { Zisovich et al., } 2004 \\
\text { Sanzol \& Herrero, } 2002^{*}\end{array}$ \\
\hline $\begin{array}{l}\text { Abbé Fétel } \\
\text { Doyenne du Comice } \\
\text { Cascade } \\
\text { Max Red Bartlett } \\
\text { Bartlett } \\
\text { Beurré Hardy } \\
\text { Eletta Morettini } \\
\text { Passe Crassane } \\
\text { Conference } \\
\text { Beurré Bosc } \\
\text { Dr.Jill Guyot } \\
\text { Red Clapp } \\
\text { Gentile } \\
\text { Spadona } \\
\text { Bon Rouge } \\
\text { Forelle } \\
\text { Spadochina } \\
\text { Lawson }\end{array}$ & $\begin{array}{l}S_{\mathrm{a}} S_{\mathrm{b}} \\
S_{\mathrm{a}} S_{\mathrm{b}} \\
S_{\mathrm{b}} S_{\mathrm{c}} \\
S_{\mathrm{e}^{-}} \\
S_{\mathrm{e}^{-}} \\
S_{\mathrm{c}} S_{\mathrm{d}} \\
S_{\mathrm{a}} S_{\mathrm{c}} \\
S_{\mathrm{a}}^{-} \\
S_{\mathrm{d}} S_{\mathrm{h}} \\
S_{\mathrm{c}^{-}} \\
S_{\mathrm{a}^{-}} S_{\mathrm{j}} \\
S_{\mathrm{d}} S_{\mathrm{j}} \\
S_{\mathrm{i}} S_{\mathrm{j}} \\
S_{\mathrm{j}} S_{\mathrm{k}} \\
S_{\mathrm{j}} S_{\mathrm{l}} \\
S_{\mathrm{j}} S_{\mathrm{n}} \\
S_{\mathrm{k}} S_{\mathrm{i}} \\
S_{\mathrm{m}} S_{\mathrm{o}}\end{array}$ & $\begin{array}{l}\text { Zuccherelli et al., 2002 } \\
\text { Zuccherelli et al., 2002 } \\
\text { Zuccherelli et al., 2002 } \\
\text { Zuccherelli et al., 2002 } \\
\text { Zuccherelli et al., 2002 } \\
\text { Zuccherelli et al., } 2002 \\
\text { Zuccherelli et al., 2002 } \\
\text { Zuccherelli et al., 2002 } \\
\text { Zuccherelli et al., 2002 } \\
\text { Zuccherelli et al., 2002 } \\
\text { Zisovich et al., 2004a } \\
\text { Zisovich et al., 2004a } \\
\text { Zisovich et al., 2004a } \\
\text { Zisovich et al., 2004a } \\
\text { Zisovich et al., 2004a } \\
\text { Zisovich et al., 2004a } \\
\text { Zisovich et al., 2004a } \\
\text { Zisovich et al., 2004a }\end{array}$ \\
\hline
\end{tabular}

*Allele designation is not reconciled with that used by Tomimoto et al. (1996)

alleles were called $S_{\mathrm{a}}, S_{\mathrm{b}}, S_{\mathrm{c}}, S_{\mathrm{d}}, S_{\mathrm{e}}$ and $S_{\mathrm{h}}$, and then all the six $S$-allele fragments were sequenced. Different degrees of fertility when crossing compatible pear cultivars were suspected to be the consequence of the action of modifier genes (Zuccherelli et al., 2002). The action of the modifier genes are hypothesized in cherry (Wünsch \& Hormaza, 2004) and peach (Hegedüs et al., 2005), as well.

Zisovich et al. (2004a) identified seven new alleles by PCR and sequencing and determined the compatibility relationships among nine cultivars. The comparison of these alleles with each other exposed a high degree of similarity among them. The results revealed that 'Spadona' $\left(S_{\mathrm{j}} S_{\mathrm{k}}\right)$, the main pear cultivar in Israel was semi-compatible with its pollinators 'Coscia', 'Gentile' and 'Spadochina' (Table I) and thereby it can explain the reason for relatively low yields. A new cultivar 'Lawson' being considered for introduction seemed to be fully compatible with 'Spadona'. In another study, the same research group (Zisovich et al., 2004b) showed that the deduced amino acid sequences of $S_{\mathrm{n}}$-RNase and $S_{\mathrm{i}}$-RNase alleles have an identical hypervariable (RHV) region. However, $S_{\mathrm{n}}$-RNase does not prevent fertilization by $S_{\mathrm{i}}$ pollen-haplotype, thus presenting a case in which RHV is not required for the determination of specific pollen rejection by $S$-RNase. The mode of the allele-specific recognition still waits for clarification in this case; however, several regions of the $S$-RNase gene may be implicated in it.

\section{Compatibility relationship of Japanese pear cultivars (Pyrus serotina Rehd. syn.: Pyrus pyrifolia Nakai)}

Many data about the self-incompatibility system were obtained in Japanese pear, as this was the first species within the Rosaceae family in which stylar ribonucleases were detected (Sassa et al., 1992). As a matter of curiosity, we mention that from the report of another Japanese research group published in the same year, low correspondence was obtained between protein bands on IEF gels and $S$-alleles, mainly due to the improper separation at the basic part of the gel. Almost all cultivars of Japanese pear exhibit selfincompatibility. Table 2 demonstrates $S$-genotypes that have been determined for a number of cultivars (Terami et al., 1946; Kajiura et al., 1967; Machida, 1972). The only selfcompatible cultivar is 'Osa-Nijisseiki', which is a mutant derived from the cultivar 'Nijisseiki' (Hirata, 1989). It was revealed that the style is unable to arrest self pollen tubes, which is attributed to a mutation of the $S_{4}$-allele (labelled as $S_{4}{ }^{\mathrm{sm}} ; \mathrm{sm}=$ stylar-part mutant) based on genetical analyses of progenies (Sato et al., 1988). It means that the pollen function is unaltered thereby 'Osa-Nijisseiki' as a male parent will show unilateral incompatibility to cultivars with an $S_{2} S_{4}$ genotype. Sassa et al. (1992) found that the $S_{4^{-}}$ related RNase band from 'Osa-Nijisseiki' was much less intense than that in the original cultivar. After silver staining of the proteins in IEF gels, the intensity of the $S_{4}$-related band was also much reduced in cv. 'Osa-Nijisseiki', which indicated a reduced level of expression in the selfcompatible genotype. Hiratsuka et al. (1995) studied the expression and inheritance of the $S_{2-}$ and $S_{4}$-alleles using progenies of self-compatible 'Osa-Nijisseiki', and totally confirmed the above described results. However, no difference was observed in the $S_{2}$-protein band between these two cultivars.

Norioka et al. (1996) cloned cDNAs for the $S_{4}$ from a stylar cDNA library, while $S_{4}^{\text {sm }}$ was neither amplified by PCR nor cloned from the library, confirming that the mutation resulted in a failure of expression of $S_{4}$-RNase. Later, the $S_{4}$-RNase could not be detected in the mutant cultivar by genomic Southern blot, indicating that the mutant lacks the gene (Sassa et al., 1997). The extent of deletion in the mutant was estimated to be more than $4 \mathrm{kbp}$, which spans the entire length of the $S_{4}$-RNase gene. Hiratsuka et al. (1999) have obtained results inconsistent with the previous findings: even at a lower level, $S_{4}$-protein was expressed in 'Osa-Nijisseiki' styles. Mechanism of self-compatibility seemed to be similar to the low levels of $S$-proteins and weak incompatibility in immature styles of self-incompatible 
'Nijisseiki'. The authors concluded that part of this protein repression might be regulated during post-transcriptional events. Later it was confirmed by showing that the depressed growth of unilateral-compatible pollen tubes ('OsaNijisseiki' $\times$ 'Kikusui') and self-pollen-tubes in 'OsaNijisseiki' is due to this small amount of biologically active $S_{4}$-RNase (Zhang \& Hiratsuka, 2005).

Later, stylar RNases associated with self-incompatibility genes were further characterized by 2D-PAGE and $\mathrm{N}$ terminal sequencing (Sassa et al., 1993). The same approach was also used to determine the amino acid sequences of $S_{\mid}$to $S_{7}$ (Ishimizu et al., 1996). Using these sequence information, and by aligning them with other rosaceous sequences, the same research group was the first to describe primary structural features of rosaceous $S$-RNases (Ishimzu et al., 1998b), and to predict topology of secondary and tertiary structures of $S$-RNases and identify putative regions for $S$-allele-specific recognition (Ishimzu et al., 1998a). A crystal structure of the $S_{3}$-RNase was determined at $1.5 \AA$ resolution, the structural features consisting 8 helices and 7 $\beta$-strands confirmed again the location and molecular role of hypervariable regions (Matsuura et al., 2001). Aphylogenetic tree of rosaceous $S$-RNases showed that $S$-RNase polymorphism predated the divergence of Pyrus and Malus (Ishimzu et al., 1998b).

Hiratsuka \& Okada (1995) investigated the $S_{3}$-protein because of its abundance and clear separation upon isoelectric focusing. They described that this protein was present only as a soluble form in the mature style. The younger styles also contain soluble $S_{3}$-protein only, suggesting that the $S$-protein is not bound chemically to cell wall and membrane in younger styles but produced gradually in the developing styles. Its concentration was the highest in the upper part of the style. The sum of two allelic $S$-proteins was found to correlate positively with the strength of SI in the cultivars (Zhang \& Hiratsuka, 1999).

The $S_{4^{-}}$and $S_{5}$-RNases could be successfully PCRamplified by apple primers (Sassa et al., 1996). The first PCR-based method for identifying $S$-genotypes of Japanese pear cultivars was performed by Ishimizu et al. (1999). It was based on primers designed from conserved regions of several apple and Japanese pear $S$-RNases and it was evaluated to be a rapid and reliable method. PCR amplification was followed by a subsequent digestion of the PCR fragments with $S$ allele-specific restriction endonucleases. Using this method, unknown $S$-genotypes of nine cultivars were determined and self-compatible genotypes were selected from the offsprings of 'Osa-Nijisseiki'.

Newer self-incompatibility RNases were described, the $S_{8}$ by Carlos et al. (2001) and the $S_{9}$ by Sawamura et al. (2002). This latter allele was further characterized by Takasaki et al. (2004) and a PCR-RFLP system was applied to distinguish $S_{1}$ to $S_{9}$; and another for the selection of selfcompatible cultivars from the progeny of the cross of 'OsaNijisseiki' and self-incompatible cultivars (Kim et al., 2004). The same authors have isolated an additional $S$-allele, $S_{10}$, from the cultivar 'Chengsilri'.
Table 2 Currently available $S$-genotypes of Japanese pear cultivars arranged to eight incompatibility groups

\begin{tabular}{|c|c|c|c|}
\hline Cultivars & S-Genotype* & Cultivars & S-Genotype* \\
\hline \multicolumn{2}{|c|}{ Self-compatible } & \multicolumn{2}{|c|}{ Group VII } \\
\hline Akibae & $S_{4}{ }^{\mathrm{sm}} S_{5}$ & Aikansui & $S_{4} S_{5}$ \\
\hline Osa-Nijisseiki & $S_{2} S_{4}{ }^{s m}$ & Asahi & $S_{4} S_{5}$ \\
\hline \multicolumn{2}{|c|}{ Group I } & Hakko & $S_{4} S_{5}$ \\
\hline Doitsu & $S_{1} S_{2}$ & Kisui & $S_{4} S_{5}$ \\
\hline Hayatama & $S_{1} S_{2}^{2}$ & Kiyozumi & $S_{4} S_{5}$ \\
\hline \multicolumn{2}{|c|}{ Group II } & Kogiku & $S_{4} S_{5}$ \\
\hline Suisei & $S_{1} S_{4}$ & Kosui & $S_{4} S_{5}$ \\
\hline Yakumo & $S_{1} S_{4}^{+}$ & Seiryu & $S_{4} S_{5}$ \\
\hline \multicolumn{2}{|c|}{ Group III } & Shinsui & $S_{4} S_{5}$ \\
\hline Ichiharawase & $S_{1} S_{5}$ & Taihaku & $S_{4} S_{5}$ \\
\hline Meigetsu & $S_{1} S_{5}$ & Waseaka & $S_{4} S_{5}$ \\
\hline \multicolumn{2}{|c|}{ Group IV } & \multicolumn{2}{|c|}{ Group VIII } \\
\hline Gion & $S_{2} S_{4}$ & Amanogawa & $S_{4} S_{9}$ \\
\hline Rokugatsu & $S_{2}^{2} S_{4}$ & Nangetsu & $S_{4}^{4} S_{9}$ \\
\hline Wasechojuro & $S_{2} S_{4}$ & Nansui & $S_{4}^{4} S_{9}$ \\
\hline Kikusui & $S_{2}^{2} S_{4}$ & Shinsei** & $S_{4}^{4} S_{9}$ \\
\hline Nijisseiki & $S_{2}^{2} S_{4}$ & Shinkou & $S_{4} S_{9}^{\prime}$ \\
\hline \multicolumn{2}{|c|}{ Group V } & \multicolumn{2}{|c|}{ Unique genotypes } \\
\hline Chikusui & $S_{3} S_{4}$ & Ch juro & $S_{2} S_{3}$ \\
\hline Ohgon-nashi & $S_{3} S_{4}$ & Hogetsu & $S_{1} S_{7}$ \\
\hline Seigyoku & $S_{3} S_{4}^{4}$ & Imamuraaki & $S_{1} S_{6}^{\prime}$ \\
\hline Shinseiki & $S_{3} S_{4}^{4}$ & Niitaka & $S_{3} S_{9}$ \\
\hline \multicolumn{2}{|c|}{ Group VI } & Okusankichi & $S_{5} S_{7}$ \\
\hline Housui & $S_{3} S_{5}$ & Shinsetsu & $S_{5} S_{6}$ \\
\hline Tanzawa & $S_{3} S_{5}$ & Yasato & $S_{2} S_{5}^{0}$ \\
\hline
\end{tabular}

*Data compiled from the following repo: $\rightarrow$ arlos et al. (2001): Ishimizu et al. (1999); Hiratsuka et al. (1998); Naher hi et al. (1992); Sassa et al. (1992): Sawamura et al. (2002): Takasaki et al. (2004)

${ }^{* *} \mathrm{Cv}$. 'Shinsei' in a diallele cross among the cultivars from the same incompatibility group showed $20-39.8 \%$ fruit set, but contained only 1.1 seed/fruit, which indicates the parthenocarpic ability of 'Shinsei"

\section{Self-incompatibility of Chinese pear (Pyrus ussuriensis)}

The only available data on the $S$-allele composition of Chinese pear cultivars were provided by Tomimoto et al. (1996). By 2D-PAGE, they have genotyped eight cultivars and found seven incompatibility alleles, described as $S_{1}-S_{7}$. Full $S$-genotypes were determined for five cultivars (involving one cross-incompatibility group) and partial $S$-genotype for three others (Table 3 ).

Table $3 \mathrm{~S}$-genotypes of Chinese pear cultivars deduced from 2D-PAGE (After Tomimoto et al., 1996)

\begin{tabular}{|l|c|}
\hline \multicolumn{1}{|c|}{ Cultivars } & S-genotype \\
\hline Lai yang ci li & $\mathrm{S}_{3} \mathrm{~S}_{4}$ \\
Ao ao li & $\mathrm{S}_{3} \mathrm{~S}_{4}$ \\
Xin qing li & $\mathrm{S}_{1} \mathrm{~S}_{2}$ \\
Hong xiao li & $\mathrm{S}_{5} \mathrm{~S}_{7}$ \\
Yuan ba li & $\mathrm{S}_{2} \mathrm{~S}_{7}$ \\
Ya li & $\mathrm{S}_{1}^{-}$ \\
Ping zi li & $\mathrm{S}_{6}^{-}$ \\
Zhu zhi li & $\mathrm{S}_{7}^{-}$ \\
\hline
\end{tabular}




\section{References}

Bellini, E., Sansavini, S., Lugli, S., Nini, S. \& Rivalta, L. (2000): Obiettivi innovatori del miglioramento genetico del pero nel mondo. Riv. Frutt Ortofloro It, 9: 56-69.

Carlos, C., Takasaki, T., Saito, T., Yohsimura, Y. \& Norioka, S. (2001): Reconsideration of $S$-genotype assignements, and discovery of a new allele based on S-RNase PCR-RFLPs in Japanese pear cultivars. Breed. Sci., 51: 5-11.

Crane, M.B. \& Lewis, D. (1942): Genetical studies in pears III. Incompatibility and sterility. J Genet, 43: 31-44.

Faostat (2003): Agriculture data. http://apps.fao.org/page/ collections $\times$ subset $=$ agriculture

Griggs, W.H. \& Iwakiri, B.T. (1954): Pollination and parthenocarpy in the production of Barlett pears in California. Hilgardia, 22: 643-678.

Hegedüs, A., Halász, J., Szabó, Z., Nyéki, J. \& Pedryc, A. (2005): Hogyan müködik a csonthéjas gyümölcsök önmeddöségét meghatározó $S$-lókusz az öntermékeny öszibarackban? Agrártudományi Közlemények, 17: 93-100.

Hirata, N. (1989): Self-compatible mutant in Japanese pear. Gamma Field Symp., 28: 71-80.

Hiratsuka, S. \& Okada, Y. (1995): Some properties of a stylar protein associated with self-incompatibility genotype of Japanese pear. Acta Hort., 392: 257-264.

Hiratsuka, S., Kubo, T. \& Okada, Y. (1998): Estimation of selfincompatibility genotype in Japanese pear cultivars by stylar protein analysis. J. Japan. Soc. Hort. Sci., 67: 491-496.

Hiratsuka, S., Nakashima, M., Kamasaki, K., Kubo, T. \& Kawai, Y. (1999): Comparison of an $S$-protein expression between self-compatible and -incompatible Japanese pear cultivars. Sex. Plant Reprod., 12: 88-93.

Hiratsuka, S., Okada, Y., Kawai, Y., Tamura, F. \& Tanabe, K. (1995): Expression and inheritance of $S$-proteins in self-compatible and incompatible Japanese pears. J. Japan. Soc. Hort. Sci. 64(3): $479-484$.

Ishimizu, T., Endo, T., Yamaguchi-Kabata, Y., Nakamura, K.T., Sakiyama, F. \& Norioka, S. (1998a): Identification of regions in which positive selection may operate in $S$-RNase of Rosaceae: Implication for $S$-allele-specific recognition sites in $S$-RNase. FEBS Lett., 440: 337-342.

Ishimizu, T., Inoue, K., Shimonaka, M., Saito, T., Terai, O. \& Norioka, S. (1999): PCR-based method for identifying the $S$ genotypes of Japanese pear cultivars. Theor. Appl. Genet., 98: 961-967.

Ishimizu, T., Sato, Y., Saito, T., Yoshimura, Y., Norioka, S., Nakanishi, T. \& Sakiyama, F. (1996): Identification and partial amino acid sequences of seven $S$-RNases associated with selfincompatibility of Japanese pear, Pyrus pyrifolia Nakai. J. Biochem., 120: 326-334.

Ishimizu, T., Shinkawa, T., Sakiyama, F. \& Nakanishi, T. (1998b): Primary structural features of rosaceous $S$-RNases associated with gametophytic self-incompatibility. Plant Mol. Biol., 37: 931-941.

Kajiura, M., Kanato, K., Machida, Y. \& Kozaki, I. (1967): New Japanese pear variety 'Shinsui' (in Japanese). Bull Hort Res Station, 6: 69-76.

Kim, H., T., Hirata, Y., Shin, Y.-U., Hwang, H.-S., Hwang, J.-H., Shin, I.-S., Kim, D.-I., Kang, S.J., Kim, H.-J., Shin, D.-Y \& Nou,
I.-S. (2004): A molecular technique for selection of self-compatible varieties of Japanese pear (Pyrus pyrifolia Nakai). Euphytica, 138: 73-80.

Machida, Y. (1972): In Dictionary of Pomology (in Japanese). 527-529, Yokendo, Tokyo.

Matsuura, T., Sakai, H., Unno, M., Ida, K., Sato, M., Sakiyama, F. \& Norioka, S. (2001): Crystal structure at 1.5-£ resolution of Pyrus pyrifolia pistil ribonuclease responsible for gametophytic self-incompatibility. J. Biol. Chem., 276: 45261-45269.

Morettini, A. (1957): La coltura del pero in Italia. II miglioramento genetico. Riv Ortofloro-Frutt It, 41: 26-40.

Norioka, N., Norioka, S., Ohnishi, Y., Ishimizu, T., Oneyama, C., Nakanishi, T. \& Sakiyama, F. (1996): Molecular cloning and nucleotide sequences of cDNAs encoding $S$-allele specific stylar RNases in a self-incompatible cultivar and its seif-compatible mutant of Japanese pear, Pyrus pyrifolia Nakai. J. Biochem., 120: 335-345.

Nyéki, J. \& Soltész, M. (2003): Pear (Pyrus communis L.). In: Floral Biology, Pollination and Fertilisation in Temperate Zone Fruit Species and Grape (Eds.: Kozma, P., Nyéki, J., Soltész, M., Szabó, Z.). pp. 237-316. Akadémiai Kiadó, Budapest.

Nyéki, J., Soltész, M. \& Ivancsics, J. (2000): Self-fertility of pear varieties conditioned by natural self-pollination (autogamy). Int. J. Hort. Sci., 6: 110-113.

Sanzol, J. \& Herrero, M. (2002): Identification of self-incompatibility in pear cultivars (Pyrus communis L.). Euphytica, 128: 325-331.

Sassa, H., Hirano, H. \& Ikehashi, H. (1993): Identification and characterization of stylar glycoproteins associated with selfincompatibility genes of Japanese pear, Pyrus serotina Rehd. Mol. Gen. Genet., 241: 17-25.

Sassa, H., Hirano, H. \& Ikehashi, H. (1992): Seifincompatibility-related RNases in styles of Japanese pear (Pyrus serotina Rehd.) Plant Cell Physiol., 33: 811-814.

Sassa, H., Hirano, H., Nishio, T. \& Koba, T. (1997): Style-specific self-compatible mutation caused by deletion of the $S$-RNase gene in Japanese pear (Pyrus serotina). Plant J., 12: 223-227.

Sassa, H., Nishio, T., Kowyama, Y., Hirano, H., Koba, T. \& Ikehashi, H. (1996): Self-incompatibility $(S)$ alleles of the Rosaceae encode members of a distinct class of the $\mathrm{T}_{2} / \mathrm{S}$ ribonuclease superfamily. Mol. Gen. Genet., 250: 547-557.

Sato, Y., Kurihara, A., Abe, K., Ogata, T., Kajiura, I., Kotobuki, K. \& Machida, I. (1988): Mode of self-compatibility inheritance in Japanese pear. Abstr Japan Soc Hort Sci Autumn Meet, 76-77.

Sawamura, Y., Saito, T., Shoda, M., Yamamoto, T., Sato, Y., Hayashi, T. \& Kotobuki, K. (2002): A new self-incompatibility allele in Japanese pear 'Shinsei' and 'Shinkou'. J. Japan. Soc. Hort. Sci.. 71: 342-347.

Szabó, T., Nyéki, J., Soltész, M., Szabó, Z. and Tóth, T. (1999): Time of flowering and fertilisation of quince varieties. Int. J. Hort. Sci., 5(1-2): 9-15.

Takasaki, T., Okada, K., Castillo, C., Moriva, Y., Saito, T., Sawamura, Y., Norioka, N., Norioka, S. \& Nakanishi, T. (2004): Sequence of the $S_{9}$-RNase cDNA and PCR-RFLP system for discriminating $S_{1}$ - to $S_{9}$-allele in Japanese pear. Euphytica, 135: $157-167$

Terami, H., Torikawa, H. \& Shimazu, Y. (1946): Analysis of the sterility factors existing in varieties of the Japanese pear (Pyrus serotina Rehd.) (in Japanese). Studies Hort. Inst. Kyoto Imp. Univ., 3: 267-271.

Tomimoto, Y., Nakazaki, T., Ikehashi, H., Ueno, H. \& Hayashi, R. (1996): Analysis of self-incompatibility-related ribonucleases 
( $S$-RNases) in two species of pears, Pyrus communis and Pyrus ussuriensis. Sci. Hortic. (Amsterdam), 66: 159-167.

Wünsch, A. \& Hormaza, J.I.. (2004): Genetic and molecular analysis in Cristobalina sweet cherry, a spontaneous selfcompatible mutant. Sex. Plant Reprod., 17:203-210.

Zhang, S.-L. \& Hiratsuka, S.: (2005): Analyses of pollen-tube growth and biological action of $S$-RNase in the style of selfcompatible Japanese pear. Sci. Hortic. (Amsterdam), 104: 169-178.

Zhang, S.-L., \& Hiratsuka, S. (1999): Variations in S-protein levels in styles of Japanese pears and the expression of selfincompatibility. J. Japan. Soc. Hort. Sci., 68: 911-918.
Zisovich, A.H., Stern, R.A., Shafir, S. \& Goldway, M. (2004a): Identification of seven $S$-alleles from the European pear (Pyrus communis) and the determination of compatibility among cultivars. J. Hortic. Sci. Biotech., 79(1): 101-106.

Zisovich, A.H., Stern, R.A., Shafir, S. \& Goldway, M. (2004b): The RHV region of S-RNase in European pear (Pyrus communis) is not required for the determination of specific pollen rejection. Sex Plant Reprod., 17: 151-156

Zuccherelli, S., Tassinari, P., Broothaerts, W., Tartarini, S., Dondini, L. \& Sansavini, S. (2002): $S$-allele characterization in seif-incompatible pear (Pyrus communis L.). Sex. Plant Reprod., 15: $153-158$. 